detailed and amply illustrated, are presonted in a most accessible and useful form.

It is difficult to find fault with this book; it would be unreasonable to do so on the narrow basis of a few omissions and inadvertent misrepresontations. It is a pleasure, therefore, to say that the second volume lives up to the standard of its predecessor to constitute a magnificent reference work on X-ray structure data, which will be greatly valued by research motallurgists and physicists.

I. WiLliams

\section{EASTERN RADIATION CHEMISTRY}

\section{Proceedings of the Second Tihany Symposium on Radiation Chemistry}

Edited by J. Dobo and P. Hedvig. Pp. xvi +813. (Budapest: Akademiai Kiado, Publishing House of the Hungarian Acadomy of Sciences, 1967.) 200s.

To those who had the pleasuro of participating in the first Tihany Conforence on Radiation Chemistry in 1962, the announcement of a second conference promised a further useful interchango of the latest information from a wide rango of sources. Subsequent reports show that this promiso was more than fulfilled and this is confirmed by the many excellent contributions reported in this volume. As may be expected, east European countries wcre strongly represented, and the meeting presented an excellent opportunity of roviowing the present status of research which, because of language difficulties, cannot always be readily followed from published literature.

Tho proceedings are divided into four main parts: general (eight papers), aqueous solutions (eighteen papers), organic compounds (thirty papers), polymors (forty-two papers). This division, however, does not reveal the wide scope of the papers. These include several papers concorned with radiation mechanisms and with radiobiology, some valuable contributions on the radiation chemistry of water and related problems and a range of papers dealing with intermediates in simple organic compounds, using recently developed techniques. An unusual feature is the largo number of contributions concerned with various aspects of polymer research: polymerization, graft and block polymers, solid state reactions, crosslinking and thermoluminescence. One of the most useful features is that many of the articles are commendably short, summarize the conclusions reached as a result of a comprehensive research programmo and give references to the original papers in which fuller details can be found. Thus, a selection of important papers not yet available in English can be made easily. This approach is to be highly recommended; only too often papers presented at conferences are too detailed and present one aspect of a lengthy programme, with which the author but not the audience is familiar; such results are more appropriately published in the usual scientific journals.

One feature of these conferences is the opportunity it offers for informal discussions in very pleasant conditions on work in progress. I have a vivid recollection after the first conference of trying to follow an informal scientific discussion in a Budapest restaurant, while a violinist of the nationalized Zigeuner Orchestra played highly romantic music at a range of six inches alternately from left and right car. For radiation chemists who have participated in this meeting and enjoyed excellent Fungarian hospitality, and for those who have not had that opportunity, this volume is most highly recommended as a souree book. On the present showing wo may expect future Tihany conferences to bocome an important feature in the calendar of international conferences on radiation chemistry, and their published proceedings a valuable collection of up to dato short roview articles.

A. Charlesby

\section{CENTURY OF STUDY}

Mongolism

Edited by G. E. W. Wolstenholme and Ruth Porter. (Ciba Foundation Study Group, No. 25.) Pp. ix +99 . (London: J. and A. Churchill, Ltd., 1967.) 18s,

Is 1866 Dr John Langdon Haydon Down published a paper "Observations on an Ethnic Classification of Idiots", in the London Hospital roports, in which he drew attention to the group of children now classed as showing the features of mongolism or Down's anomaly. Any suggestion implied in Down's paper of an ethnic link between these children and the members of the Mongolian race has long since been refuted, but the term mongolism romains in use despite atternpts to supplant it by Down's anomaly. The centenary of Down's paper was commemorated by the mecting of a study group at the Ciba Foundation in London on May 10, 1966, under the chairmanship of the late Lord Brain.

In numerical terms mongolism is important within the context of the more general problem of congenital abnormality. Children with this syndromo aro born with a frequency of about 1 in 800 of all live births, and apart from the characteristic physical stigmata they eventually show a severe degree of mental sub-normality. Mongols form an important component of the children in any hospital for the mentally sub-normal, and mongolism is possibly the example of gross congenital abnormality with which the general public is most familiar, a familiarity enhanced in recent years through the medium of television.

Seven papers were given at the Ciba meeting and six of these had roots in various advances already made in our understanding of mongolism. Dr E. Matsunaga discussed Japanese data on parental age and birth order in mongolism, while Drs H. Forssman and H. O. Akesson discussed Swedish work on consanguinity and mongolism. Both Professor L. S. Penrose and Dr G. F. Smith, of the Kennedy-Galton Centre at Harperbury Hospital, gave papers on dermatoglyphics, while Dr Ursula Mittwoch of the Galton Laboratory dealt with the DNA content of mongol and normal cells as measured by a microdensitometer on Feulgen-stained fibroblasts. Dr M. Fraccaro and collaborators from Pavia and Stockholm discussed their data on the timing of DNA replication in $G$ group autosomes in cultures of lymphocytes from mongols.

The past thirty to forty years have seen important advances in our knowledge of mongolism, and the highlights have been an appreciation of the significance of maternal age in relation to the risk of conceiving a mongol, the specificity of the dermatoglyphic findings, and the understanding that mongolism may bo tho phenotypic expression of trisomy of one of the $G$ group autosomes, conventionally regarded as No. 21 in the Denver classifica. tion. A further important advance has been the linking of familial mongolism with the transmission of a translocation ehromosome of the $D / D$ or $G / G$ centric fusion type, whilo a perplexing piece of information is tho markedly increased risk of the development of leukacmia incurred by mongol children. It is perhaps a pity that on the centenary of Dr Down's paper there was no review of the advances that had been made and of the hopes for the future. In the study of mongolism we seem to have como up to one of those barriers to the acquisition of knowledge, the successful negotiation of which opens up wide and new fields of understanding. Much of the burden of future concern in research into mongolism must surcly bo towards knowledgo of tho mechanisms linking gene action and phenotypic expression. The last paper of the Ciba meeting, by Dr W. J. Mellman and collaborators from Ponnsylvania, begins to deal with just such questions and is concerned with whether increased enzyme activities observed in the polymorphonuclear leucocytes of mongols can be accounted for by the localization of 